\title{
Changes in the expression of gallinacins, antimicrobial peptides, in ovarian follicles during follicular growth and in response to lipopolysaccharide in laying hens (Gallus domesticus)
}

\author{
Kalpana Subedi, Naoki Isobe, Masahide Nishibori and Yukinori Yoshimura \\ Graduate School of Biosphere Science, Hiroshima University, Higashi-Hiroshima 739-8528, Japan \\ Correspondence should be addressed to Y Yoshimura; Email: yyosimu@hiroshima-u.ac.jp
}

\begin{abstract}
The aim of this study was to identify the types of gallinacin genes (GALs) expressed in ovarian follicles and to determine the changes in their expression during follicular growth and in response to lipopolysaccharide (LPS). Follicles at different stages of growth were collected from laying hens $(n=5)$ and LPS-injected hens $(n=3)$. The expression of GALs in the theca and granulosa layers was examined by semi-quantitative RT-PCR. The expression of $G A L-1,-2,-7,-8,-10$, and -12 in the theca layer and GAL-1, $-8,-10$, and -12 in the granulosa layer was identified in white and yellow follicles. The expression of these genes was not changed in the theca and granulosa layers during follicular growth except for a decrease in that of GAL-1 in theca. The expression of GAL$1,-7$, and -12 in the theca layer of the third largest follicles was increased in response to LPS at a dose of $1 \mathrm{mg} / \mathrm{kg}$ body weight and this increase was induced within $3 \mathrm{~h}$ and maintained until $12 \mathrm{~h}$ postinjection. Granulosa layers did not respond to LPS until 12h injection. These results show that six and four types of GALs are expressed in the theca and granulosa layers of healthy follicles respectively, and their levels do not change with follicular growth except for GAL-1 in theca. Elevated levels of $G A L-1,-7$, and -12 expression in theca in response to LPS suggest that the theca cells expressing these GALs function to eliminate LPS-containing bacteria.

Reproduction (2007) 133 127-133
\end{abstract}

\section{Introduction}

The ovaries of mature hens consist of cortical follicles embedded in the ovarian stroma, and numerous white follicles (WF), several hierarchical yellow follicles, and postovulatory follicles (POF) protruding from the ovarian surface (Johnson 2000, Barua et al. 2001). The follicular wall consists of granulosa and theca layers, but ovarian follicles change in structure and function during follicular growth: namely, theca interna and externa develop with a decrease in the production of estrogen and increase in that of progesterone before ovulation (Gilbert 1979, Bahr et al. 1983). Ovarian follicles are the site in laying hens where foreign agents circulating in the blood accumulate (Yoshimura \& Okamoto 1998). Pathogenic microorganisms may infect hen ovarian tissues and subsequently be transmitted to the eggs (Keller et al. 1995). Salmonella enteritidis (SE) bacteria were isolated from ovaries following oral or i.v. inoculation (Keller et al. 1995, Withanage et al. 1998). Adaptive immunity via the major histocompatibility complex (MHC) and T cells has been examined in the ovarian follicles of healthy and infected birds, and the theca layers were suggested to be the major site where these immunocompetent cells reside (Barua \& Yoshimura 2004a, 2004b, Subedi \& Yoshimura 2005).

Recently, there are reports that defensin, a family of antimicrobial peptides, is one of the keys to the innate immune system which provides the initial defense against pathogens (Sugiarto \& Yu 2004). The family is divided into $\alpha, \beta$, and $\theta$ defensins. Only $\beta$-defensin exists in chickens where it is known as gallinacin (Zhao et al. 2001, Xiao et al. 2004). Gallinacins attack a wide range of microorganisms including Gram-positive and Gramnegative bacteria, fungi, and yeast (Evans et al. 1995, Harmon 1998, Sugiarto \& Yu 2004). A total of 13 different gallinacin genes (GALs), designated $G A L-1$ to -13, have been identified (Xiao et al. 2004). GAL-1 to -7 are predominantly expressed in bone marrow and respiratory tract, whereas $G A L-8$ to -13 are restricted to the liver and urogenital tract (Xiao et al. 2004). The expression of GAL-3 was observed in the ovary of immature chicken (Zhao et al. 2001). However, the expression of GALs in follicular tissue of laying hens has not been profiled. Changes in expression during 
follicular growth or during infection in ovarian tissue have not been examined either. As ovarian follicles undergo dramatic changes in structure and function during follicular growth, the immunity in this tissue may also be changed. To confirm that gallinacins participate in the defense against pathogens, it is necessary to examine whether their expression is enhanced in response to microorganisms or their components. Lipopolysaccharide (LPS) is the major cell wall constituent of Gram-negative bacteria such as Escherichia coli and Salmonella (Morrison \& Ryan 1987) and can be used to mimic bacterial infections and inflammation (Sunwoo et al. 1996, Leshchinsky \& Klasing 2003). The goal of this study was to determine the types of gallinacins that play a role in the elimination of pathogens in the follicles of laying hens, specifically, which types of GALs are expressed in ovarian follicles and whether their expression changes with follicular growth in healthy birds. Furthermore, we studied the changes in the expression of GALs in response to an injection of LPS in vivo in order to show the possibility that specific GALs expressed by follicular cells participate to attack pathogens.

\section{Materials and Methods}

\section{Experimental birds}

White Leghorn hens approximately 400-day-old and laying five or more eggs in a sequence were used. They were kept in individual cages under a $14 \mathrm{~h}$ light: $10 \mathrm{~h}$ darkness photoperiod with water and allowed to feed ad libitum. Hens were euthanized under anesthesia with sodium pentobarbital 18-20 $\mathrm{h}$ before the estimated time of ovulation ( $5 \mathrm{~h}$ after oviposition) to collect ovarian follicles as described previously (Subedi \& Yoshimura 2005). Handling of chickens was done in accordance with regulation of Hiroshima University for animal experiments.

\section{Experimental design}

In experiment 1 , the types of GALs expressed in ovarian stroma and follicles, and changes in the level of their expression with follicular growth were observed. White follicles (3-5 $\mathrm{mm}$ in diameter), the fifth and third largest follicles ( $F_{5}$ and $F_{3}$ respectively), the largest follicles $\left(F_{1}\right)$, and postovulatory follicles were collected $(n=5)$. Ovarian stroma was also collected from the ovarian cortical tissue. The outer connective tissue surrounding the surface of each follicle was removed, and theca and granulosa layers were isolated separately from the follicles as described previously (Porter et al. 1989). For the POF sample, only the theca layer was isolated.

In experiment 2, the effects of LPS on the expression of GALs in $\mathrm{F}_{3}$ were observed in vivo. A stock solution of LPS was prepared by dissolving LPS from E. coli 0111:B4
(Wako Pure Chemical Industries, Osaka, Japan) in Dulbecco's phosphate buffer (Nissui Pharmaceutical Co., Tokyo, Japan) at 0, 2, 4, and $8 \mathrm{mg} / \mathrm{ml}$. Laying hens were injected intravenously with different doses of LPS, namely at $0,0.5,1$, and $2 \mathrm{mg} / \mathrm{kg}$ body weight (BW) using the $0,2,4$, and $8 \mathrm{mg} / \mathrm{ml}$ stock solutions respectively, to know the dose-dependent effects of LPS ( $n=3$ each). The expression of each $G A L$ was examined in the theca and granulosa layers at $3 \mathrm{~h}$. Since the expression of $G A L-1,-7$, and -12 in the theca was most enhanced by LPS at a dose of $1 \mathrm{mg} / \mathrm{kg}$ BW, this concentration was used for examining the expression of GALs at different time points. The time course of changes in the expression of GALs in the theca and granulosa layers was examined at $0,3,6$, and $12 \mathrm{~h}$ after the injection of LPS $(1 \mathrm{mg} / \mathrm{kg} \mathrm{BW})(n=3)$.

To examine the tissue dependency of GAL-1, -7 , and -12 expression, their expression in the kidney and liver was also examined before and $3 \mathrm{~h}$ after the injection with $1 \mathrm{mg} / \mathrm{kg}$ BW LPS.

\section{RT-PCR and nucleotide sequencing}

RNA was extracted using sepasol RNA I super (Nacalai Tesque, Kyoto, Japan) according to the manufacturer's directions. The RNA sample was resuspended in TE buffer (10 mM Tris (pH 8.0) with $1 \mathrm{mM}$ EDTA), and treated with $10 \mathrm{U}$ DNase I (Roche Diagnostic $\mathrm{GmbH}$, Pensburg, Germany) at $37{ }^{\circ} \mathrm{C}$ for $1 \mathrm{~h}, 80^{\circ} \mathrm{C}$ for $30 \mathrm{~min}$, and $4{ }^{\circ} \mathrm{C}$ for $5 \mathrm{~min}$. Then the concentration of total RNA was determined using Gene Quant pro (Amersham Pharmacia Biotech, Cambridge, UK) and the RNA samples were stored at $-80^{\circ} \mathrm{C}$ until use.

Semi quantitative RT-PCR was performed to examine the expression of gallinacin mRNAs. The RNA samples were reverse transcribed using Rever Tra Ace (Toyobo Co. Ltd, Osaka, Japan) as described previously (Chowdhury et al. 2003). The reaction mixture $(10 \mu \mathrm{l})$ consisted of $1 \mu \mathrm{g}$ total RNA, $1 \times$ RT buffer, $1 \mathrm{mM}$ of each dNTP, $20 \cup$ RNase inhibitor, $0.5 \mu$ g oligo (dT)20, and $50 \mathrm{U}$ Rever Tra Ace. The RT was performed at $42{ }^{\circ} \mathrm{C}$ for $30 \mathrm{~min}$, followed by heat inactivation for $10 \mathrm{~min}$ at $99^{\circ} \mathrm{C}$ using a Programmable Thermal Controller, the PTC-100 (MJ Research Inc., Waltham, MA, USA). The PCR was performed in the PTC-100 in a reaction mixture of $25 \mu \mathrm{l}$ containing cDNA corresponding to $1 \mu \mathrm{g}$ of the initial total RNA, $1 \times$ PCR buffer, $0.2 \mathrm{mM}$ of each dNTP, $0.4 \mu \mathrm{M}$ of each primer, and $0.625 \mathrm{U}$ Takara Taq (Takara Bio Inc., Shiga, Japan). In order to determine the types of GALs expressed in the ovarian stroma, theca and granulosa layers of $\mathrm{WF}$ and $\mathrm{F}_{3}, \mathrm{cDNA}$ samples of these tissues were amplified using primers for all types of GALs (Table 1) at an annealing temperature ranging from 52 to $60{ }^{\circ} \mathrm{C}$ and with 40 PCR cycles. For the GALs expressed in the theca $(G A L-1,-2,-7,-8,-10$, and -12), different cycles of PCR, namely $30,35,40$, and 45 , were tested to optimize the amplification using the cDNA sample of theca tissue of $F_{3}$. A linear response for the 30 through 45 
Table 1 The PCR primer sequences with their accession numbers used in the tissue expression profiling of GALs and $\beta$-actin.

\begin{tabular}{|c|c|c|c|}
\hline Target & Primers $5^{\prime}-3^{\prime}$ & & Accession numbers \\
\hline$G A L-1$ & F-AAACCATGCGGATCGTGTACCTGC & R-CAATGCTAAACTGCACACCTTTA & AF033335 \\
\hline$G A L-2$ & F-GTTCTGTAAAGGAGGGTCCTGCCAC & R-ACTCTACAACACAAAACATATTGC & AF033336 \\
\hline$G A L-3$ & F-CTGCCGCTTCCCACACATAG & R-GCAATGCCAAACTGCACGCCTTTA & NM_204650 \\
\hline$G A L-4$ & F-ATCGTGCTCСТСТTTGTGGCAGTTCA & R-CTACAACCATCTACAGCAAGAATACT & NM_001001610 \\
\hline GAL-5 & F-ATGCAGATCСТGССТСТССТСТTTGСТ & R-TCAGGAATACCATCGGCTCCGGCAGCAGAA & NM_001001608 \\
\hline$G A L-6$ & F-GATCCTTTACCTGCTGCTGTCT & R-TCCTCACACAGCAAGATTTTAATC & NM_001001193 \\
\hline GAL-7 & F-СTGCTGTCTGTCСТСTTTGTGG & R-CATTTGGTAGATGCAGGAAGGA & NM_001001194 \\
\hline$G A L-8$ & F-ACAGTGTGAGCAGGCAGGAGGGA & R-CTCTTCTGTTCAGCCTTTGGTG & NM_001001781 \\
\hline$G A L-9$ & F-ATGAGAATCCTTTTTCTTCCTTGTTGC & R-TTAGGAGCTAGGTGCCCATTTGCAGC & NM_001001611 \\
\hline GAL-10 & F-СТGTTСТССТСТTССТСТTССАG & R-AATCTTGGCACAGCAGTTTAACA & NM_001001609 \\
\hline GAL-11 & F-ACTGCATCCGTTCCAAAGTCTG & R-TCGGGCAGCTTCTCTACAAC & NM_001001779 \\
\hline GAL-12 & F-CCCAGCAGGACCAAAGCAATG & R-GTGAATCCACAGCCAATGAGAG & NM_001001607 \\
\hline GAL-13 & F-CATCGTTGTCATTCTCСТССТC & R-ACTTGCAGCGTGTGGGAGTTG & NM_001001780 \\
\hline$\beta$-actin & F-TTCCAGCCATCTTTCTTG & R-TCCTTCTGCATCCTGTCA & X00182 \\
\hline
\end{tabular}

$F$, forward; $R$, reverse.

cycles was observed, and 35 cycles for GAL-12 and 40 cycles for $G A L-1,-2,-7,-8$, and -10 were considered optimal. Each observed GALs was amplified using an optimal number of cycles to examine changes in their expression level during follicular growth and in response to LPS in both theca and granulosa layers. The cycle parameters were denaturation at $94{ }^{\circ} \mathrm{C}$ for $30 \mathrm{~s}, 30$ cycles (for $\beta$-actin) or 35 cycles (for GAL-12) or 40 cycles (for $G A L-1$ to -11$)$ of denaturation at $94{ }^{\circ} \mathrm{C}$ for $30 \mathrm{~s}$, annealing at $58^{\circ} \mathrm{C}$ (for $\beta$-actin, $G A L-3,-4,-5,-6,-7$, $-9,-10$, and -11 ) or $60{ }^{\circ} \mathrm{C}$ (for $G A L-1,-2,-8$, and -12) for $30 \mathrm{~s}$ for all GALs or $1 \mathrm{~min}$ for $\beta$-actin, and extension at $72{ }^{\circ} \mathrm{C}$ for $1 \mathrm{~min}$, and a final extension at $72{ }^{\circ} \mathrm{C}$ for $6 \mathrm{~min}$. $\beta$-actin was used for standardization for each gallinacins. PCR products were separated by electrophoresis on 3\% $(\mathrm{w} / \mathrm{v})$ agarose gels containing ethidium bromide $(0.5 \mathrm{mg} /$ $\mathrm{ml}$ ) and photographed under UV illumination. Densitometry was performed using a Gel-Pro analyzer (Media Cybernetics, Silver Spring, MD, USA), and the ratio of gallinacin mRNA to $\beta$-actin mRNA was obtained.

The PCR products of obtained GALs were sequenced using a Big Dye terminator Sequence Kit (ver. 3.1, Applied Biosystems, Foster City, USA) with an ABI 3100 automated sequencer (Applied Biosystems, Foster City, USA), as described previously (Ohashi et al. 2005) to confirm correspondence to the sequences in GenBank.

\section{Statistical analysis}

The results were expressed as the actual mean \pm S.E.M. of the ratio of $G A L$ to $\beta$-actin mRNA. Prior to analysis, data were first analyzed by Bartlett's test to ensure homogeneity of variance. If significance was found for a particular parameter (where raw data were heterogeneous), square root transformations were performed. The significance of differences was examined using a one-way ANOVA followed by Duncan's multiple range test. The KruskalWallis one-way ANOVA was used when unequal variances were found even after transformation. Expression levels of GALs in liver and kidney were compared between control and treated groups using Student's $t$-test. A difference with a $P$ value of $<0.05$ was considered statistically significant.

\section{Results}

\section{Experiment 1}

Out of the 13 GALs reported, 6 GALs (GAL-1, $-2,-7,-8$, -10 , and -12) were observed in the theca layer and 4 GALs (GAL-1, -8, -10, and -12) in the granulosa layer of white and yellow follicles, WF and $F_{3}$ (Fig. 1 A and B respectively). Twelve types of GALs (GAL-1 to -12) were observed in the ovarian stroma (Fig. 1C). The expression of GAL-13 was not observed in both ovarian stroma and follicles. The expression of GAL-3, -4, -5, -6, -9, and -11 was also not observed in ovarian follicles. The expression of GAL-1 was significantly decreased in the theca layer with follicular growth (Fig. 2A). However, the levels of expression of GAL-2, -7, -8, -10, and -12 in the theca layer were not different among $W F, F_{5}, F_{3}, F_{1}$, and POF (Fig. 2B-F respectively). The expression of $G A L-1,-8,-10$, and -12 in granulosa layer did not show a significant difference among $W F, F_{5}, F_{3}$, and $F_{1}$ (data not shown).

\section{Experiment 2}

The expression of GAL-1, -7 , and -12 in the theca layer of $\mathrm{F}_{3}$ was enhanced by LPS at a dose of $1 \mathrm{mg} / \mathrm{kg}$ BW, although levels declined to those of the control at $2 \mathrm{mg} / \mathrm{kg}$ BW (Fig. 3A, C, and F respectively). Only the expression of $G A L-8$ in the theca layer was enhanced by LPS at a dose of $2 \mathrm{mg} / \mathrm{kg}$ BW (Fig. 3D). The expression of GAL-2 and -10 was not enhanced in response to LPS at the doses examined in this study (Fig. $3 \mathrm{~B}$ and $\mathrm{E}$ respectively). The expression of GAL-1 in the granulosa layer of $\mathrm{F}_{3}$ was decreased by LPS at $0.5-2 \mathrm{mg} / \mathrm{kg}$ BW (Fig. 4A). The expression of GAL-8, -10 , and -12 in the 
A

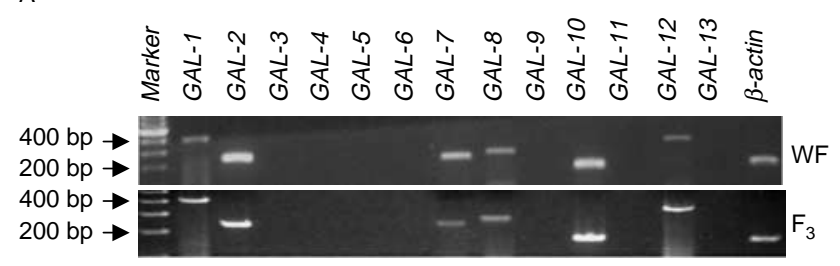

B

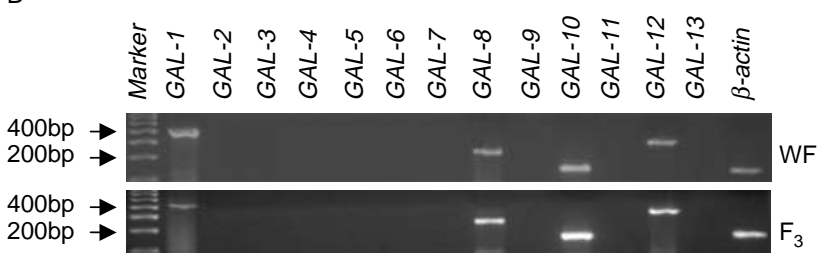

C

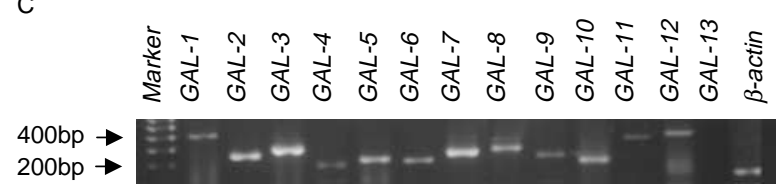

Figure 1 Expression pattern of gallinacin mRNA (GALs) determined by RT-PCR analysis in the (A) theca and (B) granulosa layers of WF and F3, and $(C)$ ovarian stroma of laying hen. Out of 13 reported gallinacins, $G A L-1,-2,-7,-8,-10$, and -12 are observed in the theca layer, whereas $G A L-1,-8,-10$, and -12 are expressed in the granulosa layer.

granulosa layer did not respond to LPS at doses of $0.5,1$, and $2 \mathrm{mg} / \mathrm{kg}$ BW (Fig. 4B-D respectively).

Changes in the expression of GALs in the theca layer of $\mathrm{F}_{3} 0,3,6$, and $12 \mathrm{~h}$ after the administration of LPS $(1 \mathrm{mg} / \mathrm{kg}$ BW) are shown in Fig. 5. The expression of $G A L-1,-7$, and -12 was significantly increased at $3 \mathrm{~h}$ when compared with $0 \mathrm{~h}$ and remained relatively high until $12 \mathrm{~h}$ postinjection (Fig. $5 \mathrm{~A}, \mathrm{C}$, and $\mathrm{F}$ respectively). The GAL-2, -8 , and -10 in the theca layer did not respond to LPS during $12 \mathrm{~h}$ (Fig. 5B, D, and $\mathrm{E}$ respectively).

The expression of GAL-8 and -10 in the granulosa layer of $\mathrm{F}_{3}$ did not show a significant difference until $12 \mathrm{~h}$ after the administration of LPS (Fig. 6B and C respectively). However, the expression of GAL-1 and -12 in the granulosa layer of $F_{3}$ decreased at $3 \mathrm{~h}$ and was low at or until $12 \mathrm{~h}$ (Fig. $6 \mathrm{~A}$ and $\mathrm{D}$ respectively).

Unlike in the theca layer, the levels of the expression of $G A L-1,-7$, and -12 in kidney and liver were not affected by 3-h postinjection of $1 \mathrm{mg} / \mathrm{kg}$ BW of LPS (data not shown).

\section{Discussion}

We are the first to report the expression of gallinacins, antimicrobial peptides, in ovarian follicles and changes in them during follicular growth and in response to LPS. The noteworthy findings were: (1) out of the 13 GALs reported to date, 12, 6, and 4 types were expressed in the ovarian stroma, theca, and granulosa layers of WF and hierarchical yellow follicles $\left(F_{3}\right)$ respectively, $(2)$ mRNA levels of these GALs in the theca and granulosa layers did
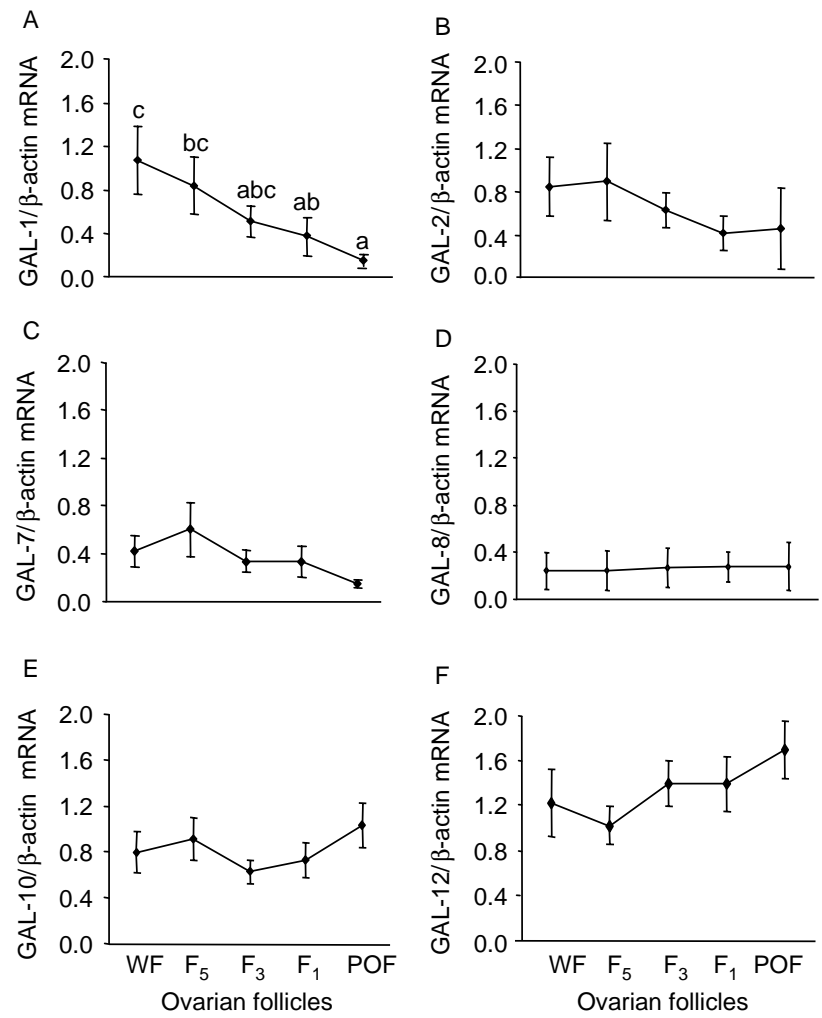

Figure 2 Changes in the expression of gallinacin mRNA (GALs) in the theca during follicular growth in laying hens. (A) GAL-1, (B) GAL-2, (C) GAL-7, (D) GAL-8, (E) GAL-10, and (F) GAL-12. The values are the mean \pm S.E.M. of the ratio of GALs to $\beta$-actin mRNA $(n=5)$. WF, white follicles; $F_{5}$, the fifth largest follicles; $F_{3}$, the third largest follicles; $F_{1}$, the largest follicles; and POF, the largest postovulatory follicles. Means with different letters differ significantly $(P<0.05)$.

not change with follicular growth, except for a decline in the expression of GAL-1 in the theca layer, and (3) the injection of LPS in vivo enhanced the expression of $G A L-1,-7$, and -12 in the theca layer of $\mathrm{F}_{3}$ but not in the granulosa layer.

The current study showed that GAL-1, -2, -7, $-8,-10$, and -12 were expressed in the theca cells and $G A L-1,-8$, -10 , and -12 in the granulosa cells of laying hens. Theca layer is a heterogeneous tissue consisting of fibroblastlike cells, interstitial cells, nerve cells, and endothelial cells of capillaries (Gilbert 1979, Yoshimura \& Bahr 1995). GAL-2 and -7 that observed in the theca but not in the granulosa might be expressed in these theca cells. Although Zhao et al. (2001) found the expression of GAL-3 in the ovary of immature hens, this expression was not observed in both theca and granulosa layers in the current study. Our study showed that the ovarian stromal tissue expressed 12 types of GALs (GAL-1 to -12) including $G A L-3$. Stromal cells are likely to express more GALs than theca and granulosa cells. Thus, the expression of GAL-3 in the ovary of immature hen observed by Zhao et al. (2001) might be due to the expression in the stroma rather than follicular cells. 

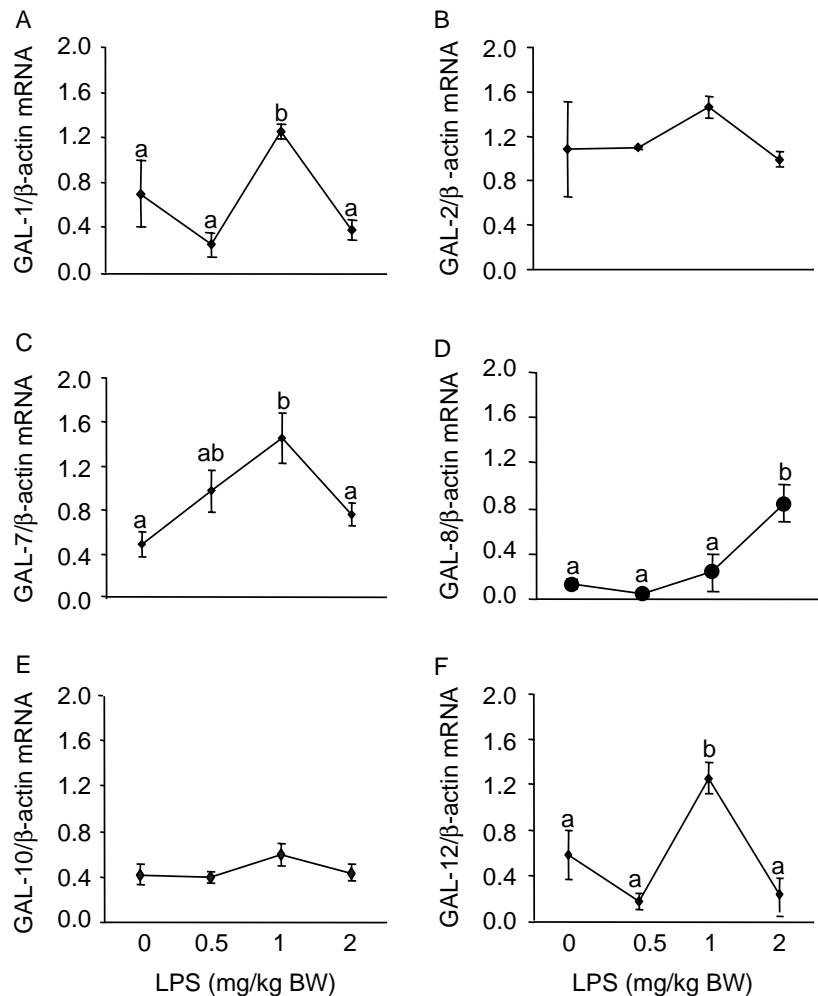

Figure 3 Changes in the expression of gallinacin mRNA (GALs) in the theca layer of $\mathrm{F}_{3}$ at doses of $0,0.5,1$, and $2 \mathrm{mg} / \mathrm{kg}$ BW of LPS after $3 \mathrm{~h}$ injection. (A) GAL-1, (B) GAL-2, (C) GAL-7, (D) GAL-8, (E) GAL-10, and (F) $G A L-12$. The values are the mean \pm s.E.M. of the ratio of $G A L$ to $\beta$-actin mRNA $(n=3)$. Means with different letters differ significantly $(P<0.05)$.

Out of six types of theca GALs, GAL-2, $-7,-8,-10$, and -12 did not change in their expression, whereas the level of GAL-1 decreased during follicular growth and postovulation. None of the four types of GALs in the granulosa cells changed with follicular growth. The most
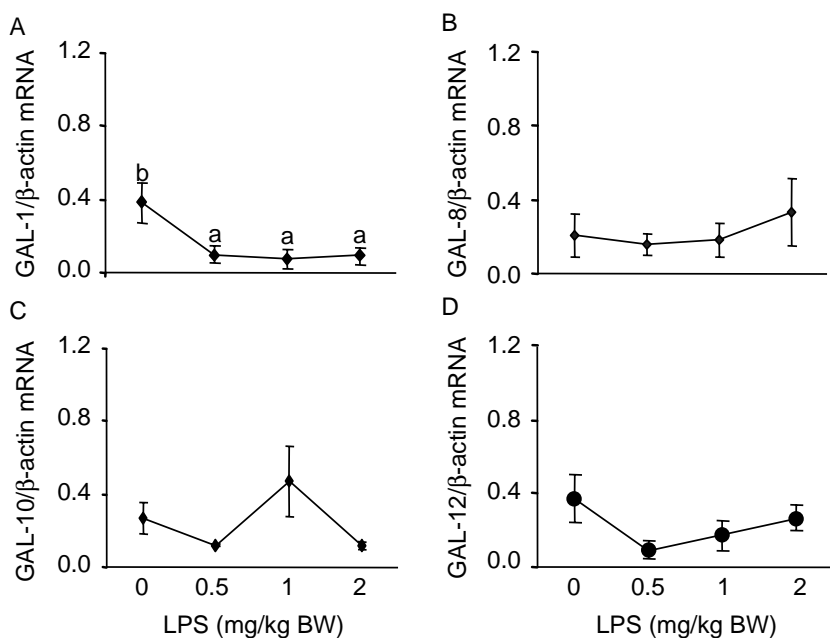

Figure 4 Changes in the expression of gallinacin mRNA (GALs) in the granulosa layer of $F_{3}$ at doses of $0,0.5,1$, and $2 \mathrm{mg} / \mathrm{kg} \mathrm{BW}$ of LPS after 3h injection. (A) GAL-1, (B) GAL-8, (C) GAL-10, and (D) GAL-12. See Fig. 3 for other explanations.
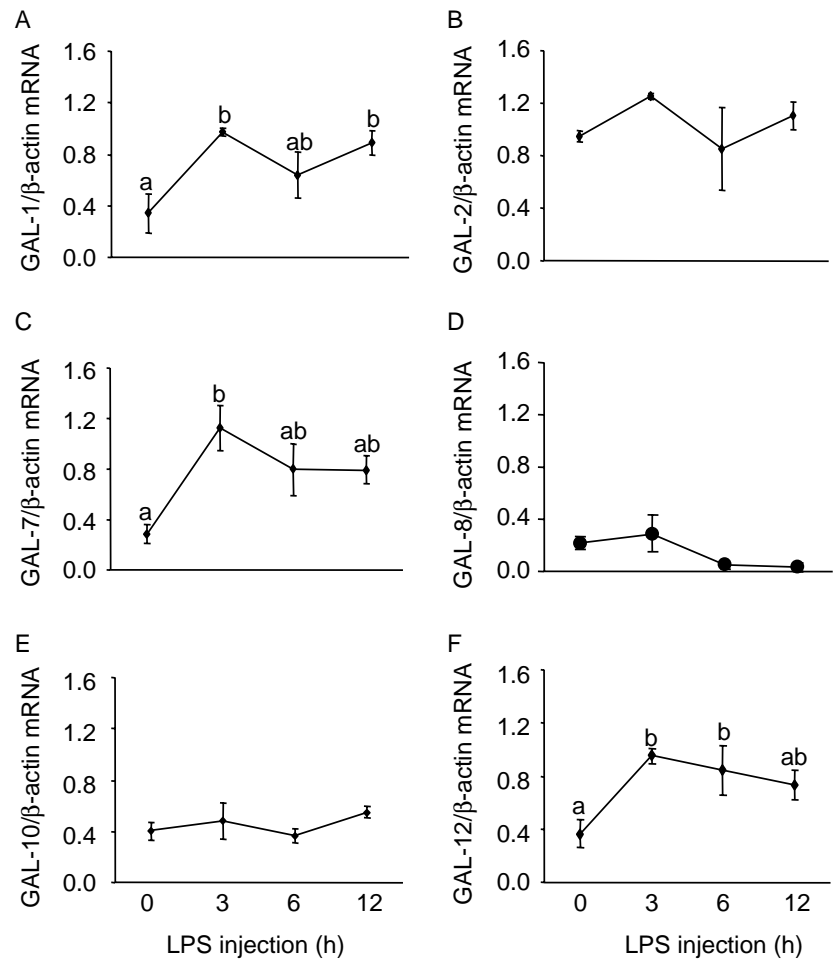

Figure 5 Changes in the expression of gallinacin mRNA (GALs) in the theca layer of $\mathrm{F}_{3}$ at different time points after the injection of $0,3,6$, and $12 \mathrm{~h}$ of LPS ( $1 \mathrm{mg} / \mathrm{kg} \mathrm{BW})$. The values are the mean \pm s.E.M. of the ratio of $G A L$ to $\beta$-actin mRNA $(n=3)$. (A) GAL-1, (B) GAL-2, (C) GAL-7, (D) GAL-8, (E) GAL-10, and (F) GAL-12. Means with different letters differ significantly $(P<0.05)$.

distinct change in the matured ovarian tissue is the development of follicles during follicular growth, including the differentiation of theca into theca externa and interna layers with the development of a vascular architecture and proliferation of granulosa cells (Gilbert 1979). We have observed that the theca cell proliferation was high in growing follicles, although it was decreased from $F_{3}$ to $F_{1}$ (Yoshimura et al. 1996). The current study suggests that although the follicular structure are changed with growth, the expression of GALs in the theca and granulosa layers, except for theca $G A L-1$, is unchanged during follicular growth under normal conditions. Only the theca expression of GAL-1 that decreased in association with follicular growth might be affected by the follicular cell population and/or the change in their functions during the growth of follicles.

The expression of theca GAL-1, -7 , and -12 was enhanced in response to $1 \mathrm{mg} / \mathrm{kg}$ BW of LPS within $3 \mathrm{~h}$ injection and remained at relatively high levels until $12 \mathrm{~h}$, although $2 \mathrm{mg} / \mathrm{kg}$ BW of LPS did not increase the expressions. The expression of $G A L-8$ was not enhanced by $1 \mathrm{mg} / \mathrm{kg}$ BW of LPS until $12 \mathrm{~h}$, whereas it was enhanced by $2 \mathrm{mg} / \mathrm{kg}$ BW of LPS. However, the expression of GAL-2 and -10 was not affected by LPS. Thus, we show that at least the theca cells are able to respond to LPS and the expression of $G A L-1,-7$, and -12 

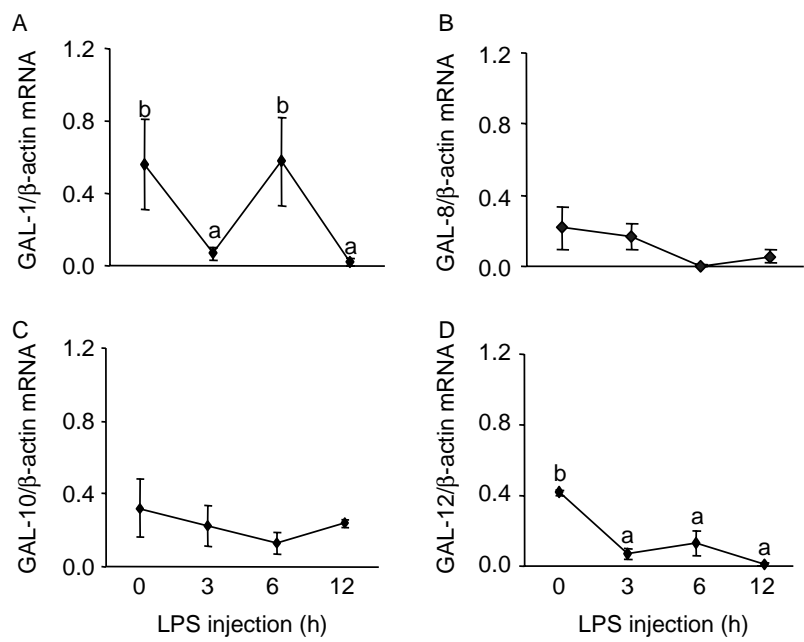

Figure 6 Changes in the expression of chicken gallinacin mRNA (GALs) in the granulosa layer of $F_{3}$ at different time points after the injection of $0,3,6$, and $12 \mathrm{~h}$ of LPS (1 mg/kg BW). (A) GAL-1, (B) GAL-8, (C) GAL10, and (E) GAL-12. See Fig. 5 for other explanations.

is enhanced. It remains to be studied whether theca cells expressing GAL-2 and -10 are stimulated by other pathogenic agents. The expressions of $G A L-1,-7$, and -12 were not enhanced in kidney and liver within 3-h LPS injection $(1 \mathrm{mg} / \mathrm{kg}$ BW), which enhanced the expressions in theca. These results show that the effects of LPS on GALs expression was different among the tissues, and the theca layer is more sensitive to LPS and/or respond earlier to it than kidney and liver.

The theca gallinacins, whose gene expression was enhanced by LPS, are expected to act on pathogenic microorganisms such as Salmonella and E. coli to eliminate them from the follicular tissues. Furthermore, these gallinacins may play a role in inducing adaptive immunity to antigens by inducing the formation of immunocompetent cells. In mammals, $\beta$-defensins exert chemotactic effects on dendritic cells and resting memory $\mathrm{T}$ cells to link innate immunity with the adaptive immune system (Yang et al. 1999, Oppenheim et al. 2003, Wu et al. 2003). We have demonstrated that the i.p. or i.v. inoculation of laying hens with Salmonella antigens increased numbers of MHC class II expressing cells, and $\mathrm{CD}^{+}{ }^{+}$and $\mathrm{CD}^{+} \mathrm{T}$ cells in the theca layer of white and larger yellow follicles (Yoshimura \& Takata 2002, Barua \& Yoshimura 2004a). The theca GALs whose level of expression was increased by LPS may mediate part of that process.

In the granulosa cells, four types of GALs, GAL-1, -8, -10 , and -12 were expressed, but they were not enhanced by LPS unlike in the theca layer, and rather, the expression of GAL-1 and - 12 tended to decline after the injection of LPS (Figs 4 and 6). The reason why the expression of some of the GALs was decreased is unknown. We suggest that the theca layer is the primary site where gallinacins are synthesized in response to bacterial antigens in vivo.
In conclusion, we show that 12 types of GALs in the stroma, 6 in the theca layer and 4 in the granulosa layer are expressed in healthy follicles, and their expression in the follicles does not change with follicular growth except for a decrease in theca GAL-1. Among the follicular cells expressing these GALs, those expressing $G A L-1,-7$, and -12 could respond to LPS, suggesting that GALs are involved in defense against Gram-negative bacteria. The theca tissue where GAL expression was increased in response to LPS may be the primary site for such a system of defense.

\section{Acknowledgements}

Authors would like to thank Dr T Bungo for helpful suggestions for statistical analysis and Mr Y Yamashita for analysis of the density of PCR bands. This work was supported by a Grantin-aid for Scientific Research from the Japan Society for the Promotion of Science. The authors declare that there is no conflict of interest that would prejudice the impartiality of this scientific work.

\section{References}

Bahr JM, Wang SC, Huang MY \& Calvo FO 1983 Steroid concentration in isolated theca and granulosa layers of preovulatory follicles during the ovulatory cycle of the domestic hen. Biology of Reproduction 29 326-334.

Barua A \& Yoshimura Y 2004a Ovarian cell-mediated immune response to Salmonella enteritidis infection in laying hens (Gallus domesticus). Poultry Science 83 997-1002.

Barua A \& Yoshimura Y 2004b Changes in the expression of major histocompatibility complex class II mRNA in response to inoculation with Salmonella enteritidis in cultured hen ovarian tissue. Journal of Poultry Science 41 281-288.

Barua A, Michiue H \& Yoshimura Y 2001 Changes in the localization of MHC class II positive cells in hen ovarian follicles during the processes of follicular growth, postovulatory regression and atresia. Reproduction 121 953-957.

Chowdhury VS, Nishibori M \& Yoshimura Y 2003 Changes in the expression of TGF $\beta$-isoforms in the anterior pituitary during withdrawal and resumption of feeding in hens. General and Comparative Endocrinology 133 1-7.

Evans EW, Beach FG, Moore KM, Jackwood MW, Glisson JR \& Harmon BG 1995 Antimicrobial activity of chicken and turkey heterophil peptides CHP1, CHP2, THP1, and THP3. Veterinary Microbiology 47 295-303.

Gilbert AB 1979 Female genital organs. In Form and Function in birds vol 1, pp 237-360. Eds AS King \& J McLelland. London: Academic Press.

Harmon BG 1998 Avian heterophils in inflammation and disease resistance. Poultry Science 77 972-977.

Johnson AL 2000 Reproduction in the Female. In Sturkie's Avian Physiology, 5 edn, pp 569-596. Ed GC Whittow. New York: Academic Press.

Keller LH, Benson CE, Krotec K \& Eckroade RJ 1995 Salmonella enteritidis colonization of the reproductive tract and forming and freshly laid eggs of chicken. Infection and Immunity 63 2443-2449.

Leshchinsky TV \& Klasing KC 2003 Profile of chicken cytokines induced by lipopolysaccharide is modulated by dietary $\alpha$-tocopheryl acetate. Poultry Science 82 1266-1273.

Morrison DC \& Ryan JL 1987 Endotoxins and disease mechanisms. Annual Review of Medicine 38 417-431. 
Ohashi H, Subedi K, Nishibori M, Isobe N \& Yoshimura Y 2005 Expressions of antimicrobial peptide gallinacin-1, -2 and -3 mRNAs in the oviduct of laying hens. Journal of Poultry Science 42 337-345.

Oppenheim JJ, Biragyan A, Kwak LW \& Yang D 2003 Roles of antimicrobial peptides such as defensins in innate and adaptive immunity. Annals of the Rheumatic Diseases 62 17-21.

Porter TE, Hargis BM, Silsby JL \& El Halawani ME 1989 Differential steroid production between theca interna and theca externa cells: a three-cell model for follicular steroidogenesis in avian species. Endocrinology 125 109-116.

Subedi K \& Yoshimura Y 2005 Expression of MHC class I and II in growing ovarian follicles of young and old laying hens, Gallus domesticus. Journal of Poultry Science 42 101-109.

Sugiarto H \& Yu PL 2004 Avian antimicrobial peptides: the defense role of $\beta$-defensins. Biochemical Biophysical Research Communications $323721-727$.

Sunwoo HH, Nakano T, Dixon WT \& Sim JS 1996 Immune responses in chickens against lipopolysaccharide of Escherichia coli and Salmonella typhimurium. Poultry Science 75 342-345.

Withanage GSK, Sasai K, Fukata T, Miyamoto T \& Baba E 1998 T lymphocytes, B lymphocytes, and macrophages in the ovaries and oviducts of laying hens experimentally infected with Salmonella enteritidis. Veterinary Immunology and Immunopathology 66 173-184.

Wu Z, Hoover DM, Yang D, Boulegue C, Santamaria F, Oppenheim JJ, Lubkowski J \& Lu W 2003 Engineering disulfide bridges to dissect antimicrobial and chemotactic activities of human defensin 3. PNAS $1008880-8885$.

Xiao Y, Hughes AL, Ando J, Matsuda Y, Cheng JF, Skinner-Noble D \& Zhang G 2004 A genome-wide screen identifies a single $\beta$-defensin gene cluster in the chicken: implications for the origin and evolution of mammalian defensins. BMC Genomics 5 56-66.
Yang D, Chertov O, Bykovskaia SN, Chen Q, Buffo MJ, Shogan J, Anderson M, Schröder JM, Wang JM, Howard OMZ \& Oppenheim JJ $1999 \beta$-defensins: linking innate and adaptive immunity through dendritic and T Cell CCR6. Science 286 525-528.

Yoshimura Y \& Bahr M 1995 Atretic changes of follicular wall caused by destruction of the germinal disc region of an immature preovulatory follicle in the chicken: an electron microscope study. Journal of Reproduction and Fertility 105 147-151.

Yoshimura Y \& Okamoto T 1998 Phagocytosis of carbon particles by theca interna fibroblasts in hen ovary. Japanese Poultry Science 35 314-318.

Yoshimura Y \& Takata T 2002 Effects of intravenous injection of Salmonella antigen on the distribution of major histocompatibility complex class II positive cells in the ovarian follicles of hen. Animal Science Journal 73 369-373.

Yoshimura Y, Okamoto T \& Tamura T 1996 Proliferation of granulosa and thecal cells in germinal disc and non-disc regions during follicular growth in Japanese quail (Coturnix coturnix japonica): bromodeoxyuridine incorporation in situ. Journal of Reproduction and Fertility 107 125-129.

Zhao C, Nguyen T, Liu L, Sacco RE, Brogden KA \& Lehrer RI 2001 Gallinacin-3, an inducible epithelial $\beta$-defensin in the chicken. Infection and Immunity $692684-2691$.

Received 27 June 2006

First decision 23 September 2006

Accepted 2 October 2006 